\title{
Histological features predictive of liver fibrosis in chronic hepatitis $\mathrm{C}$ infection
}

\author{
V Paradis, P Mathurin, A Laurent, F Charlotte, M Vidaud, T Poynard, C Hoang, \\ P Opolon, P Bedossa
}

Service d'Anatomie Pathologique, Hôpital de Bicêtre, Paris, France

V Paradis

P Bedossa

Service

d'Hépatogastro-

entérologie, groupe

hospitalier

Pitié-Salpétriêre,

Paris, France

P Mathurin

T Poynard

P Opolon

Service d'Anatomie

Pathologique

F Charlotte

C Hoang

CNRS URA 1484

Faculté de Pharmacie,

Paris VII, France

$M$ Vidaud

V Paradis

P Bedossa

P Mathurin

T Poynard

A Laurent

Correspondence to: Dr P Bedossa, Service

d'Anatomie Patholice

d'Anatomie Pathologique,

Hôpital de Bicêtre, 78 rue

général Leclerc, 94275

Paris, France.

Accepted for publication 16 April 1996

\begin{abstract}
Aims-To assess which pathological features are associated with a sensitive marker of liver fibrogenesis and thus of the potential development of fibrosis in hepatitis $\mathbf{C}$.

Methods-The degree of liver fibrogenesis was evaluated by quantification of type I collagen mRNA and transforming growth factor (TGF) $\beta 1$ mRNA (a major profibrogenic cytokine) in liver biopsy specimens from 28 patients with chronic hepatitis $C$ and five controls, using a quantitative reverse transcription polymerase chain reaction (RT-PCR) assay. Results of mRNA quantification were correlated with histological lesions scored semiquantitatively in the same specimens.

Results-Type I collagen mRNA was more strongly expressed in patients than in controls and correlated with the degree of fibrosis, but not with any of the necroinflammatory lesions (portal inflammation, piecemeal necrosis, and lobular necrosis). TGF $\beta 1$ mRNA concentration was higher in patients than in controls and correlated with histological grade of activity and lobular necrosis. This result was confirmed by in situ hybridisation experiments which showed that TGF $\beta 1$ mRNA was mainly expressed in areas of focal lobular necrosis in chronic hepatitis $\mathrm{C}$. Conclusion-This study shows that fibrosis, rather than necro-inflammatory lesions or activity scores, is associated with fibrogenesis and thus with potential aggravation of the fibrous deposit in chronic hepatitis C. Lobular necrosis is an important predictor of prognosis in chronic hepatitis $\mathrm{C}$, as shown by its strong association with TGF $\beta 1$ mRNA expression. (F Clin Pathol 1996;49:998-1004)
\end{abstract}

Keywords: chronic hepatitis C, liver fibrogenesis, in situ hybridisation, TGF $\beta 1$ mRNA.

The course of chronic hepatitis $\mathrm{C}$ virus (HCV) infection, even after antiviral treatment, is difficult to predict. Although the disease is frequently asymptomatic, the development of liver fibrosis is common, and cirrhosis, occurring in about one in five cases, is the major complication of this chronic disease. ${ }^{1}$ There are no reliable biological or clinical indicators that can predict which patients will develop fibrosis, but if found, these would also help select appropriate patients for antiviral treatment.
Liver biopsy is used to assess the extent of liver damage, as a means of monitoring disease progression, and as a source of information for correct management. Histological examination of the liver biopsy specimens allows activity and fibrosis to be assessed. ${ }^{23}$ Activity gives an overall picture of the degree of necro-inflammatory lesions (grade), while fibrosis reflects the disruption to the liver architecture (stage). ${ }^{2}$ It has been suggested that in hepatitis B virus infection fibrosis is the result of activity, and thus histological activity might predict the subsequent development of fibrosis or cirrhosis. ${ }^{4}$ This hypothesis has been extended to chronic hepatitis C so that the presence of histological activity is a major criterion for starting antiviral treatment. However, this has been challenged, as data from several series of liver biopsy specimens from patients with chronic hepatitis $C$ showed that activity is usually mild, but that fibrosis and cirrhosis are common findings. ${ }^{6-8}$ As far as we are aware no studies have assessed the predictive value of these different histological features in terms of the aggravation of liver fibrosis in chronic hepatitis C.

Liver tissue can also be used to investigate tissue markers of ongoing fibrogenesis, a complex process that examines the different extracellular matrix (ECM) components, such as collagens, fibronectin, and proteoglycans. ${ }^{9}{ }^{10}$ In liver fibrosis and cirrhosis, collagens, especially type I collagen, are much in evidence. ${ }^{11}$ Furthermore, type I collagen mRNA seems to be a definitive and reliable marker for fibrogenic activity and so of potential fibrous deposition. ${ }^{12} 13$

The aim of this study was to determine the pathological features associated with the potential progression to fibrosis in chronic hepatitis C. We therefore evaluated the degree of fibrogenesis in liver biopsy specimens by quantification of liver type I collagen mRNA, using a sensitive quantitative reverse transcriptionpolymerase chain reaction (RT-PCR) assay. We also performed semiquantitative scoring of the different pathological features present in the same liver biopsy specimens and assessed the correlations between histological scores and type I collagen mRNA concentration.

As transforming growth factor (TGF) $\beta 1$ has a major role in the pathogenesis of fibrosis in chronic hepatitis and cirrhosis-mainly by stimulation of fat storing cells, the main cellular source of matrix proteins ${ }^{14}{ }^{15}$-we also quantified its mRNA concentration in the same biopsy specimens and correlated it with histological variables. TGF $\beta 1$ mRNA expres- 
sion was also studied using in situ hybridisation and the results compared with quantitative data.

\section{Methods}

Twenty eight patients (nine women and 19 men; mean age 48 years, range 29-69 years) were included in the study. All patients were positive for antibody to $\mathrm{HCV}$ by second generation tests. Serum viral load was quantified by branched DNA (Amplec Chiron, Chriron, Emeryville, California, USA). Genotypes were also determined by a competitive oligonucelotide priming (COP) PCR assay in 21 patients. ${ }^{16}$ Serum aminotransferases (ALT), bilirubin, and $\gamma$-glutamyltranspeptidase were measured on entry to the study. None of the patients had received antiviral treatment. The delay between presumed infection and time of inclusion was determined for 19 patients. Selection of patients was based on consecutive recruitment and on the availability of enough liver tissue to perform both an accurate histological study and RNA extraction for mRNA quantification.

Twelve patients received interferon $\alpha 2 b$ (Intron-A, Schering Plough, UK) in a dose of 3 $\mathrm{mU}$, three times weekly for six months. Two patients were non-responders (no improvement in ALT activity during treatment), four were partial responders (decrease of less than $50 \%$ of initial value of ALT), and six were complete responders (return to normal of ALT values).

Five patients without $\mathrm{HCV}$ infection, normal liver function tests, and neither chronic hepatitis nor fibrosis on the biopsy specimen, constituted the control group.

Liver biopsy specimens were obtained for each patient using a percutaneous procedure. About half of each specimen was immediately frozen in liquid nitrogen and stored at $-80^{\circ} \mathrm{C}$ until RNA extraction was performed; the rest of the specimen was fixed, embedded in paraffin wax and processed for histological study according to standard procedures.

A set of representative paraffin wax embedded liver biopsy specimens showing chronic $\mathrm{HCV}$ infection with differing degrees of activity were selected for in situ hybridisation. These were cut into $5 \mu \mathrm{m}$ thick sections.

HISTOLOGICAL ANALYSIS OF LIVER BIOPSY SPECIMENS

Liver biopsy specimens were examined simultaneously by two different pathologists, neither of whom was aware of clinical and biological data except for positivity for antibody to $\mathrm{HCV}$.

For each liver biopsy specimen, the semiquantitative assessment of elementary features potentially present in HCV hepatitis was performed using a standardised questionnaire. ${ }^{17}$ The following lesions were recorded: portal fibrosis $(\mathrm{F} 0=$ no fibrosis, $\mathrm{F} 1=$ portal fibrosis without septa, $\mathrm{F} 2=$ portal fibrosis with rare septa, F3 = numerous septa without cirrhosis, F4 $=$ cirrhosis $)$; focal lobular necrosis $(0=$ less than one necro-inflammatory focus per lobule, $1=$ at least one necro-inflammatory focus per lobule, 2 $=$ several necro-inflammatory foci per lobule or confluent or bridging necrosis); portal inflammation ( $0=$ absent, $1=$ presence of mononuclear aggregates in some portal tracts, $2=$ mononuclear aggregates in all portal tracts, $3=$ large and dense mononuclear aggregates in all portal tracts); and piecemeal necrosis ( $0=$ absent, $1=$ focal alteration of periportal plate in some portal tracts, 2 = diffuse alteration of periportal plate in some portal tracts or focal lesions around all portal tracts, 3 = diffuse alteration of periportal plate in all portal tracts). Fatty changes (micro and/or macrovesicular) were graded as $0=$ absent, $1=$ mild, $2=$ moderate, $3=$ severe. Bile duct damage was also reported.

The activity of chronic hepatitis was recorded as follows: $\mathrm{A} 0=$ no histological activity, $\mathrm{A} 1=$ minimal activity, $\mathrm{A} 2=$ moderate activity, A3 = severe activity. The degree of disease activity was defined by the integrated assessment of all necro-inflammatory lesions according to an algorithm, including piecemeal necrosis as a major decision criterion and lobular necrosis as a secondary criterion. The reproducibility of this activity grading was reported as acceptable according to a previous study. ${ }^{17}$ Finally, the histological activity index of Knodell et al ${ }^{18}$ (periportal \pm bridging necrosis, lobular necrosis, inflammation and portal fibrosis scores) was separately recorded.

Total RNA was isolated from frozen liver tissue using a method derived from the procedure of Chomczynski and Sacchi. ${ }^{19}$ The concentration and purity of total RNA were evaluated by spectrophotometry at 260 and $280 \mathrm{~nm}$. The quality of RNA was also controlled by electrophoresis on a $1 \%$ agarose gel by checking the $18 \mathrm{~S}$ and $28 \mathrm{~S}$ RNA bands.

Type I collagen and TGF $\beta 1$ mRNA of each liver biopsy specimen were quantified by a quantitative RT-PCR assay. ${ }^{20}$ Expression of an endogenously expressed RNA (transcription factor TFIID) was used as the internal control for each specimen. Each sample was normalised on the basis of its internal control content (TFIID).

Reverse transcription of total RNA was performed in a final volume of $20 \mu \mathrm{l}$ containing $1 \times$ RT-PCR buffer ( $1 \mathrm{mM}$ each dNTP, $5 \mathrm{mM}$ $\mathrm{MgCl}_{2}, 50 \mathrm{mM} \mathrm{KCl}, 10 \mathrm{mM}$ TRIS- $\mathrm{HCl}, \mathrm{pH}$ 8.3), 1 unit of RNase inhibitor, 50 units of Moloney murine leukaemia virus reverse transcriptase (RT) (Perkin-Elmer, Foster City, California, USA), $2.5 \mathrm{mM}$ random hexamers, and $1 \mu \mathrm{g}$ of total RNA. Samples were incubated at $20^{\circ} \mathrm{C}$ for 10 minutes, $42^{\circ} \mathrm{C}$ for 30 minutes, and reverse transcriptase was inactivated by heating at $99^{\circ} \mathrm{C}$ for five minutes and cooled at $5^{\circ} \mathrm{C}$ for five minutes. Thereafter, the $20 \mu \mathrm{l}$ volume was brought to $100 \mu$ with $1 \times$ RT-PCR buffer.

Quantitative PCR is based on coamplification of specific cDNA with a quantitative DNA standard (QDS) using the same pair of primers. ${ }^{20}$ Specific QDS were generated by creating a 12 base pair insertion in the wild type cDNA sequence for each target gene. QDS were constructed by PCR from cDNA using a composite primer. With this procedure, target cDNA and QDS yield labelled PCR products of different sizes which were identi- 
Table 1 Oligonucleotide primer sequences and PCR product sizes (base pairs)

\begin{tabular}{lll}
\hline Gene & Primer sequence & PCR product size \\
\hline \multirow{2}{*}{ Type I collagen } & 5'-TCCCCAGCCACAAAGAGTCTACA-3' & 155 \\
& 5'-F-GTGATTGGTGGGATGTCTTCGTC-3' & \\
TGF $\beta 1$ & 5'-CAACAATTCCTGGCGATACCTCA-3' & 199 \\
& 5'-F-GGTAGTGAACCCGTTGATGTCCA-3' & \multirow{2}{*}{ TFIID } \\
& 5'-F-ACAGGAGCCAAGAGTGAAGAA'3' & 260 \\
& 5'-CCAGAAACAAAAATAAGGAGA-3' & \\
\hline
\end{tabular}

$\mathrm{F}=$ Fluorescein molecule
IN SITU HYBRIDISATION

A cocktail of single stranded oligonucleotides, chemically synthesised, and modified at the $5^{\prime}$ end with digoxigenin by the manufacturer ( $R$ and D Systems Inc., Minnesota, USA) was used. It consisted of an equimolar mixture of three exon specific probes based on the antisense sequence of exon 6 (28 mer), exon 7A (27 mer), and exon 7B (26 mer) of the TGF $\beta 1$ gene.

In situ hybridisation was performed on paraffin wax embedded liver sections, as described before. ${ }^{21}$ Briefly, sections were dewaxed in xylene and graded ethanol, rinsed in DEPC water for five minutes, and treated with proteinase $\mathrm{K}$ at a final concentration of 10 $\mu \mathrm{g} / \mathrm{ml}$ for 10 minutes at $37^{\circ} \mathrm{C}$ in $50 \mathrm{mM}$ TRIS, $\mathrm{pH}$ 7.6. Slides were post-fixed in $0.4 \%$ paraformaldehyde in $1 \times \mathrm{PBS}$ for 20 minutes at $4^{\circ} \mathrm{C}$. Liver sections were then hybridised overnight at $37^{\circ} \mathrm{C}$ in $4 \times$ SSC, $50 \%$ formamide, $1 \times$ Denhart's solution, $5 \%$ dextran sulphate, 0.5 $\mathrm{mg} / \mathrm{ml}$ salmon sperm DNA, $0.25 \mathrm{mg} / \mathrm{ml}$ yeast tRNA containing $500 \mathrm{ng} / \mathrm{ml}$ of digoxigenin labelled TGF $\beta 1$ antisense probe. After washing in decreasing concentrations of SSC (sodium citrate/sodium chloride) (twice for five minutes in $4 \times \mathrm{SSC}$ at $37^{\circ} \mathrm{C}$, twice for five minutes in $2 \times$ SSC at $37^{\circ} \mathrm{C}$, and once in $1 \times$ SSC for $15 \mathrm{~min}-$ utes at room temperature), tissue sections were incubated with anti-digoxigenin antibody at a 1 in 500 dilution (Boehringer Mannheim, Mannheim, Germany) in $100 \mathrm{mM}$ TRIS- $\mathrm{HCl}, 150$ $\mathrm{mM} \mathrm{NaCl}, \mathrm{pH} 7.5$, for 20 minutes at $37^{\circ} \mathrm{C}$. After two rinses in the same buffer for five minutes and washing in DEPC-water with levamisole $1 \mathrm{mM}$, alkaline phosphatase was detected using 5-bromo-4-chloro-3-indolyl phosphate and nitro blue tetrazolium chloride.

Digoxigenin labelled sense oligonucleotide as well as sections incubated without probe were used as negative controls. Liver sections incubated with a digoxigenin labelled poly-dT oligoprobe and recombinant $\mathrm{CHO}$ cell lines expressing TGF $\beta 1$ incubated with the TGF $\beta 1$ antisense probe were used as positive controls. These controls were systematically processed in each experiment and under the same conditions. Genescan 672 Software (Applied Biosystems). PCR products of target CDNA and corresponding QDS are represented by two different peaks of fluorescence. The area of each peak, expressed in relative fluorescence units (RFU), was correlated with the amount of PCR product. Results for each gene were expressed as a ratio between target cDNA RFU and its corresponding QDS RFU. Experiments were performed twice with three sets for each data point.

Results are presented as mean (SD) unless otherwise stated. Variability of the different assessments was estimated by standard deviation and coefficient of variation. Statistical analysis was performed using Student's $t$ test and the Mann-Whitney $U$ test. When necessary, statistics were performed after logarithmic transformation of the data. Correlations between type I collagen, TGF $\beta 1$ mRNA concentrations with the different histological scores, clinical and biological data were performed using Pearson's test.

\section{Results}

The mean delay between presumed infection and liver biopsy was 16.8 months (range seven to 40 months) in the 19 patients for whom data were available. The mean (SD) values of serum ALT, bilirubin, and $\gamma$-glutamyltranspeptidase were, respectively: $2.9 \mathrm{~N}$ (2.1), 9.4 (3.61) $\mu \mathrm{mol} / 1$ and $5 \mathrm{~N}(0.8)(\mathrm{N}=$ upper limit). Ten patients were genotype $1 \mathrm{~b}$, three were genotype $1 \mathrm{a}$, one was genotype $2 \mathrm{a}$, five were genotype $3 \mathrm{a}$, and the other two could not be determined using the current procedure.

For each liver biopsy specimen, the principal histological features and the degree of activity according to the METAVIR and Knodell index are reported in table 2. According to METAVIR, fibrosis was graded as $F 1$ in 10 patients, $\mathrm{F} 2$ in nine patients, $\mathrm{F} 3$ in eight, and F4 in one. ${ }^{17}$ One patient had no activity (A0), 12 had 
Table 2 Clinical, biological and histological data for 28 patients with HCV infection and five controls

\begin{tabular}{|c|c|c|c|c|c|c|}
\hline $\begin{array}{l}\text { Patient } \\
\text { number }\end{array}$ & Sexlage & $\begin{array}{c}\text { Type I collagen } \\
m R N A^{\star}\end{array}$ & $\begin{array}{c}\text { TGFB1 } \\
m R N A^{\star}\end{array}$ & $\begin{array}{l}\text { Fibrosis } \\
\text { scoret }\end{array}$ & $\begin{array}{c}\text { Activity } \\
\text { grade } \neq\end{array}$ & $\begin{array}{l}\text { Knodel } \\
\text { index }\end{array}$ \\
\hline 1 & $F / 64$ & 1.37 & 0.45 & 3 & 2 & 10 \\
\hline 2 & $\mathrm{M} / 57$ & 6.18 & 0.71 & 4 & 2 & 10 \\
\hline 3 & $\mathrm{M} / 54$ & 7.37 & 0.57 & 3 & 2 & 11 \\
\hline 4 & $\mathrm{M} / 44$ & 0.79 & 0.16 & 2 & 2 & 10 \\
\hline 5 & $F / 69$ & 3.67 & 0.66 & 3 & 1 & 8 \\
\hline 6 & $\mathrm{M} / 37$ & 1.4 & 0.17 & 3 & 1 & 5 \\
\hline 7 & M/61 & 1.2 & 0.35 & 1 & 2 & 6 \\
\hline 8 & $F / 64$ & 0.62 & 0.94 & 1 & 2 & 10 \\
\hline 9 & $\mathrm{M} / 68$ & 0 & 0.89 & 3 & 3 & 11 \\
\hline 10 & M/68 & 0.72 & 0 & 1 & 0 & 5 \\
\hline 11 & M/36 & 0.99 & 0.64 & 1 & 2 & 6 \\
\hline 12 & $\mathrm{M} / 40$ & 0 & 0.25 & 1 & 1 & 8 \\
\hline 13 & $M / 35$ & 1.9 & 0.36 & 1 & 1 & 6 \\
\hline 14 & $\mathrm{M} / 30$ & 5.71 & 0.78 & 1 & 1 & 6 \\
\hline 15 & $F / 33$ & 1.1 & 0.42 & 2 & 1 & 7 \\
\hline 16 & $\mathrm{M} / 58$ & 2.88 & 0.88 & 2 & 2 & 12 \\
\hline 17 & $\mathrm{M} / 57$ & 2.29 & 0.54 & 2 & 1 & 5 \\
\hline 18 & $F / 63$ & 2.31 & 0.76 & 1 & 2 & 8 \\
\hline 19 & $\mathrm{M} / 29$ & 1.48 & 0.29 & 3 & 2 & 10 \\
\hline 20 & $F / 29$ & 0.45 & 0.2 & 1 & 1 & 5 \\
\hline 21 & $\mathrm{~F} / 54$ & 1.63 & 0.57 & 3 & 1 & 7 \\
\hline 22 & $M / 41$ & 1.86 & 0.97 & 3 & 2 & 10 \\
\hline 23 & $M / 56$ & 0.54 & 0.66 & 1 & 2 & 10 \\
\hline 24 & $M / 36$ & 0.59 & 0.46 & 2 & 1 & 7 \\
\hline 25 & $M / 47$ & 0.19 & 0.37 & 2 & 1 & 8 \\
\hline 26 & $F / 34$ & 0.28 & 0.35 & 2 & 1 & 10 \\
\hline 27 & $F / 43$ & 0.4 & 0.26 & 2 & 2 & 10 \\
\hline 28 & $M / 37$ & 0.27 & 0.04 & 2 & 2 & 10 \\
\hline \multicolumn{7}{|l|}{ Controls } \\
\hline 29 & M/49 & 0.51 & 0.16 & 0 & 0 & 0 \\
\hline 30 & $M / 33$ & 0.5 & 0.13 & 0 & 0 & 0 \\
\hline 31 & $\mathrm{M} / 2$ & 0.34 & 0.28 & 0 & 0 & 0 \\
\hline 32 & $F / 43$ & 0.45 & 0.1 & 0 & 0 & 0 \\
\hline 33 & $M / 51$ & 0.36 & 0.07 & 0 & 0 & 0 \\
\hline
\end{tabular}

^Results of mRNA quantification are normalised to TFIID mRNA content in the same sample. to $=$ No fibrosis; $1=$ portal fibrosis without septa; $2=$ portal fibrosis with rare septa; $3=$ numerous septa without cirrhosis; $4=$ cirrhosis.

$\ddagger 0=$ No histological activity; $1=$ minimal activity; 2 = moderate activity; $3=$ severe activity.

Table 3 Correlations between type I collagen and TGF $1 \mathrm{mRNA}$ and histological features in liver biopsy specimens of patients with chronic hepatitis $C$

\begin{tabular}{llllll}
\hline & \multicolumn{2}{l}{ Type I collegen } & $m$ mNA & & \multicolumn{2}{c}{ TGFß1 $m R N A$} & \\
\cline { 2 - 3 } \cline { 5 - 6 } Histology & $r^{*}$ & p value & & $r^{*}$ & p value \\
\hline Fibrosis score & 0.39 & 0.03 & & 0.29 & 0.08 \\
Lobular necrosis & 0.21 & NS & & 0.47 & 0.01 \\
Piecemeal necrosis & 0.02 & NS & & 0.27 & NS \\
Portal inflammation & 0.10 & NS & & 0.20 & NS \\
Activity (grade) & 0.13 & NS & & 0.53 & 0.003 \\
Knodell index & 0.18 & NS & & 0.43 & 0.02 \\
\hline
\end{tabular}

^Pearson's correlation coefficient.

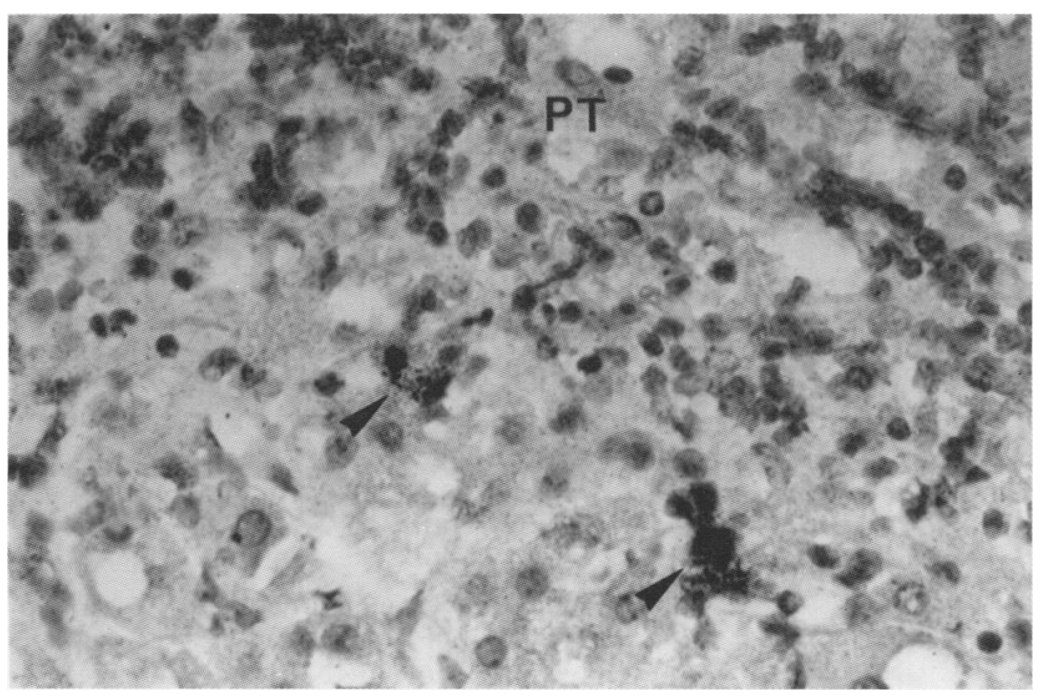

Figure 1 In situ hybridisation of TGF 1 in liver biopsy specimens of chronic active hepatitis C. TGF $1 \mathrm{mRNA}$ was detected in some inflammatory and sinusoidal cells of the periportal area (arrow). $P T=$ portal tract. mild activity (A1), 14 had moderate activity (A2), and one had severe activity (A3). The mean value of the Knodell index was 8.3 (2.2) (range $5-12) .^{18}$

Type I collagen and TGF $\beta 1 \mathrm{mRNA}$ were quantified in the livers of 28 patients with chronic hepatitis $\mathrm{C}$ and in five controls. The concentrations of type I collagen and TGF $\beta 1$ mRNA in each subject were normalised to that of the TFIID mRNA value in the same biopsy sample. The mean coefficients of variation of triplicate assessments of TFIID, type I collagen, and TGF $\beta 1 \mathrm{mRNA}$ in the 30 samples were, respectively: 0.06 (range $0.02-0.10$ ), $0.11(0.04-0.15$ ), and 0.06 (range 0.01-0.09).

In the control group the mean concentration of type I collagen mRNA was $0.43(0.08)$ and that of TGF $\beta 1$ mRNA was $0.15(0.08)$. In patients with chronic hepatitis C type I collagen mRNA was 1.7 (1.9), which was significantly higher than that in the control group $(p<0.01)$. The mean TGF $\beta 1$ mRNA in patients with chronic hepatitis $C$ was $0.5(0.3)$, significantly higher than that of the control group $(\mathrm{p}<0.01)$.

The concentration of TGF $\beta 1$ mRNA correlated significantly with type I collagen mRNA concentration $(\mathrm{r}=0.45 ; \mathrm{p}=0.02)$.

CORRELATIONS BETWEEN TYPE I COLLAGEN

MRNA AND BIOLOGICAL AND HISTOLOGICAL DATA In chronic hepatitis $C$ patients, the concentration of type I collagen mRNA correlated with neither the biological data nor the delay in contamination. No correlation was observed between type I collagen mRNA and the HCV genotype (1.8 (2.1) and $1.2(1.1)$ in the $1 \mathrm{~b}$ compared with the non-1b genotype groups). Nor was there any correlation observed with the extent of HCV viraemia.

Among the different primary pathological features assessed, fibrosis was the only lesion to be correlated with the type I collagen mRNA concentration $(r=0.39 ; p=0.03)$. The mean concentration of type I collagen mRNA was significantly lower in the 20 patients with $\mathrm{F} 1$ or $\mathrm{F} 2(1.2(1.3))$ than in the eight patients with $\mathrm{F} 3$ or F4 (2.9 (2.6); $\mathrm{p}=0.03)$ fibrosis. No correlation was observed with other histological features. Results are shown in details in table 3.

Among patients with significant fibrosis (F>F2), mean type I collagen mRNA was not significantly different between patients with no or mild activity ( $\mathrm{A} 0$ or $\mathrm{A} 1, \mathrm{n}=8,1.4(1.2)$ ) and those with moderate or severe activity (A2 or $\mathrm{A} 3, \mathrm{n}=10,2.3(2.5)$ ).

To analyse in more detail the correlation between type I collagen mRNA and histological features, the patients were divided into two groups according to the concentration of type I collagen mRNA: those with higher than the median value $(>1.1, \mathrm{n}=15)$ and those with lower than the median value $(<1.1, \mathrm{n}=13)$. Comparisons between these two groups showed that the degree of fibrosis was significantly higher in the group of patients with higher type I collagen mRNA than in the other group (2.3 (1.0) vs $1.5(0.7) ; \mathrm{p}=0.01)$. No significant difference was observed for other histological features. 


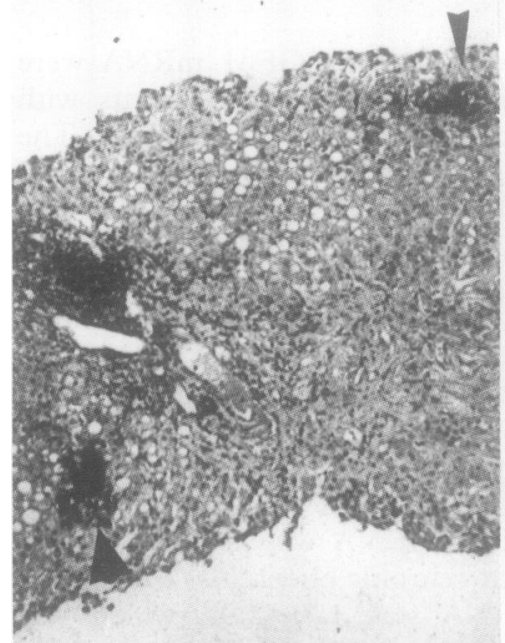

B

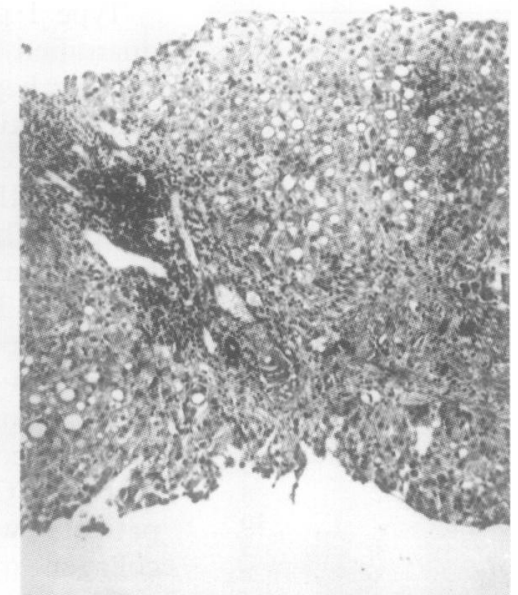

Figure 2 In situ hybridisation of TGFß1 $m R N A(A)$. At low magnification, large amounts of TGFB1 mRNA was detected in the lobule (arrow); PT= portal tract. In situ hybridisation (B). Serial section hybridised with TGF 1 sense probe. No staining was seen.

CORRELATIONS BETWEEN TGF $\beta 1$ MRNA AND BIOLOGICAL AND HISTOLOGICAL DATA

In chronic patients with hepatitis $C$ no correlation was observed between the concentration of TGF $\beta 1$ mRNA and any biological data studied. There was also no correlation with the HCV genotype $(0.6(0.2)$ and $0.4(0.2)$ in the $1 \mathrm{~b}$ compared with the non-1b genotype groups) or the extent of $\mathrm{HCV}$ viraemia ( $\mathrm{r}=$ $0.1)$.

TGF $\beta 1$ mRNA correlated significantly with lobular necrosis, with histological activity according to the METAVIR score and with the Knodell index. There was a trend for correla-

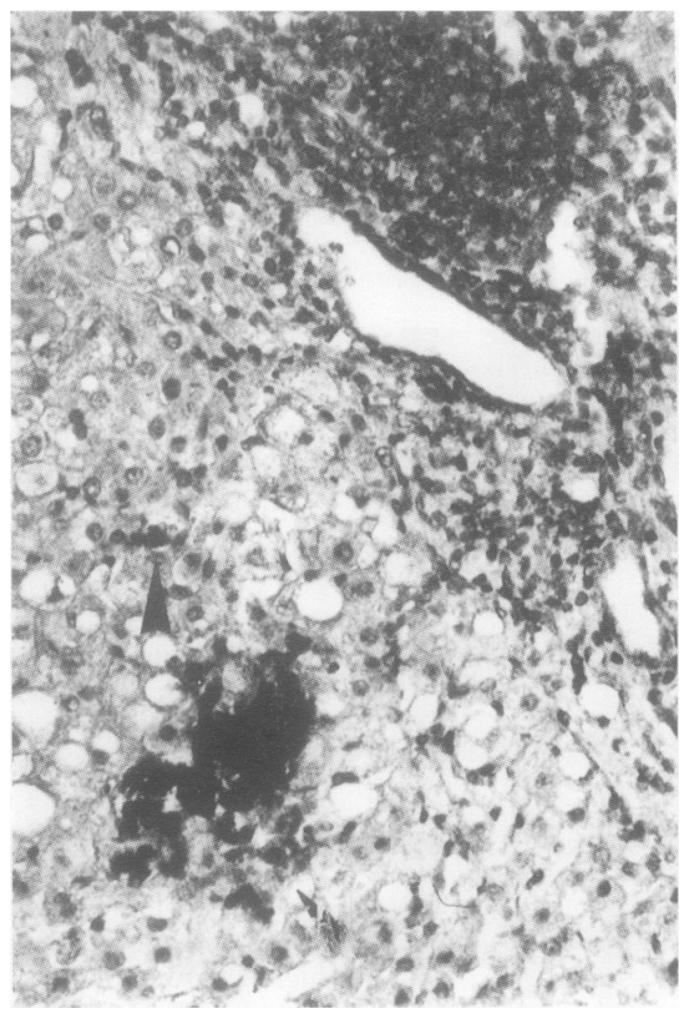

Figure 3 In situ hybridisation of TGF 1 mRNA. TGF 1 $m R N A$ was detected in areas of lobular necrosis and in perisinusoidal cells (arrow) close to this area.

tion with fibrosis. Other features were not correlated with the TGF $\beta 1$ mRNA (table 3).

The patients were divided into two groups according to the concentration of TGF 1 mRNA: those with above the median value $(>0.4, \mathrm{n}=16)$ and those with below $(<0.4, \mathrm{n}=$ 12). Comparisons between these two groups showed that the degree of lobular necrosis and histological activity according to METAVIR was significantly higher in the group of patients with TGF $\beta 1$ mRNA than the other group (lobular necrosis: $0.9(0.4)$ vs $0.4(0.4), \mathrm{p}=$ 0.03 ; activity $1.7(0.6)$ vs $1.1(0.8), \mathrm{p}=0.04)$. A significant trend was also observed for fibrosis $(1.5(0.9)$ vs $2.2(1.0), \mathrm{p}=0.06)$. No significant differences were observed for other histological features.

The mean concentration of type I collagen mRNA in the non- or partial responders was higher but not significantly different (1.95 (2.45)) from that in the complete responders (0.66 (0.66)). TGF $\beta 1 \mathrm{mRNA}$ was also higher, but not significantly different $(0.56(0.3))$, in the non- or partial responders from that in complete responders $(0.39(0.28))$.

In liver biopsy specimens of chronic hepatitis C TGF $\beta 1$ mRNA was expressed in isolated mononuclear cells of portal tracts and periportal inflammatory infiltrate as well as in some cells of the hepatic capsule (fig 1). In chronic hepatitis with severe activity, the major source of TGF $\beta 1 \mathrm{mRNA}$ was detected in the liver lobule (fig 2A). An intense signal was observed in focal areas of lobular necrosis composed of aggregates of mononuclear inflammatory cells in contact with a few necrotic liver cells. Close to these areas, TGF $\beta 1$ transcripts were also detected in perisinusoidal cells (fig 3 ). No expression was observed neither in hepatocytes nor in biliary cells. No staining was detected in negative controls (fig 2B).

\section{Discussion}

In chronic liver disease development of fibrosis induces substantial changes in the liver structure. Because this evolution is frequently, but not always, observed in $\mathrm{HCV}$ infection, it is important to have histological indicators that can predict liver fibrosis and thus help in the selection of patients for treatment. An ideal study would be to follow up untreated patients with chronic hepatitis $\mathrm{C}$ by sequential liver biopsy, and then to deduce which features present on initial biopsy specimens are associated with further development of fibrosis. Such a study is not feasible, largely for ethical reasons. To predict the development of liver fibrosis, we quantified liver type I collagen mRNA, a sensitive marker of active fibrogenesis. Type I collagen is one of the major extracellular matrix components in liver fibrosis, ${ }^{9-11}$ and an increase in expression of its mRNA is a necessary early step in the fibrogenic process. ${ }^{12} 22-24$

To quantify accurately the mRNA, we used a quantitative RT-PCR procedure, as conventional methods of mRNA analysis, such as northern and dot blotting, are neither sensitive nor accurate enough. ${ }^{25} 26$ This method uses endogenously expressed RNA as an internal 
control to monitor the extent of degradation and recovery of mRNA, and to control sample to sample variations. For this reason, we quantified TFIID in each biopsy sample, a consistently expressed transcriptional factor. For each sample, results of mRNA quantification (type I collagen and TGF $\beta 1$ ) were expressed on the basis of its internal control (TFIID) content.

Type I collagen mRNA expression was increased in patients with chronic hepatitis $C$. A wide range of mRNA values was observed in this group and it may be related to the sampling of patients, based only on an anti-HCV positive serology irrespective of an increase in transaminase activity or histological lesion.

To assess the histological lesions reflecting ongoing fibrogenesis, we correlated type I collagen mRNA with semiquantitative scores of the different histological lesions. Interobserver variation is a major drawback in the semiquantitative assessment of histological features in hepatitis C. ${ }^{17}$ To minimise interobserver variations, two pathologists experienced in liver pathology performed simultaneous readings of all biopsy specimens, as we had already shown that this procedure significantly decreased interobserver variations. ${ }^{17}$ Analysis of results showed that the degree of fibrosis was the only histological lesion that correlated with the type I collagen mRNA concentration. This result means that, in chronic hepatitis $\mathrm{C}$, a preexisting fibrosis is a predictive histological indicator of further aggravation of fibrosis.

None of the necro-inflammatory lesions, whether taken independently or combined in a scoring system, correlated with an increase in type I collagen mRNA, either throughout the whole group of patients or in the group of patients with clinically important fibrosis. Our data suggest that fibrosis is at least as important as grade in the prediction of further fibrosis. These results also underline the usefulness of independent assessment of activity (grade) and fibrosis (stage), as recently recommended. ${ }^{23}$ If these results are confirmed in a larger group the presence of fibrosis, whatever the degree of histological activity, would have to be considered when selecting patients for treatment.

Our study shows that TGF $\beta 1$ mRNA is highly correlated with histological grade according either to METAVIR $^{17}$ or the Knodell index. ${ }^{18}$ Furthermore, among the different primary necro-inflammatory features, only lobular necrosis correlates with the increase in TGF $\beta 1 \mathrm{mRNA}$ value. This finding emphasises the importance of this histological feature in the global assessment of necro-inflammatory features (activity) and in the fibrogenetic process in hepatitis C. Results of our in situ hybridisation experiments confirm these data. Like other similar studies ${ }^{24} 27$ we detected TGF $\beta 1 \mathrm{mRNA}$ in some portal and periportal inflammatory cells in chronic hepatitis C. Furthermore, when activity was pronounced, we found that a major site of TGF $\beta 1 \mathrm{mRNA}$ production were areas of focal lobular necrosis and that perisinusoidal cells adjacent to these areas of lobular necrosis also strongly expressed TGF $\beta 1$ mRNA. Taken together, these results fit well with the concept that, in chronic hepa- titis C, aggravation of chronic histological lesions occurs throughout episodes of lobular necrosis. $^{2}$

Discrepancies exist concerning a correlation between TGF $\beta 1$ mRNA concentration and piecemeal necrosis or portal inflammation. While Castilla et $a l^{2}$ found a significant correlation between the TGF $\beta 1$ mRNA concentration and all necro-inflammatory lesions included in the Knodell index, Roulot et $a l^{9}$ found none. These differences could be explained by patient sampling as some studies included patients with both chronic hepatitis B and $\mathrm{C},{ }^{22}$ or else by the different mRNA quantification procedures used. Another major factor is the accuracy of the histological analysis, as we have already shown high interobserver variations in the assessment of histological lesions in chronic hepatitis C, especially necroinflammatory features such as piecemeal necrosis and portal inflammation. ${ }^{17}$

Several studies have emphasised the importance of the HCV genotype and viral load in the severity of disease and the treatment response. ${ }^{30}$ We found no correlations between either type I collagen or TGF $\beta 1$ mRNA with the HCV genotype or viral load. Furthermore, although higher type I collagen and TGF $\beta 1$ mRNA concentrations were observed in the non- or partial responders than in the complete responders, differences did not reach significance.

We have shown that the expression of type I collagen mRNA in the liver correlates with TGF $\beta 1$ mRNA. This agrees with previous studies using semiquantitative mRNA procedures. ${ }^{22} 23$ Furthermore, in our study, we found a trend for correlation between an increase in the TGF $\beta 1 \mathrm{mRNA}$ concentration and semiquantitative scoring of fibrosis. These results suggest that TGF $\beta 1$ has a role in the fibrogenesis in hepatitis $C$.

In conclusion, our study shows that the histological features of necro-inflammation and fibrosis differ in their correlation with a sensitive marker of fibrogenesis in chronic hepatitis C. This underlines the importance of separate assessment of these two features in chronic hepatitis $\mathrm{C}$ liver biopsy reports. The correlation between lobular necrosis and TGF $\beta 1$ mRNA suggests a major role for this lesion in chronic hepatitis $\mathrm{C}$.

This work was supported by a research grant from Association pour la Recherche Contre le Cancer.

1 Soni P, Duseiko GM, Harrison TJ, Dhillon AP. Genetic diversity of hepatitis $C$ virus: implications for pathogenesis, treatment, and prevention. Lancet 1995;345:562-6.

2 Scheuer PJ. Classification of chronic viral hepatitis: a need for reassessment. F Hepatol 1991;13:372-4.

3 Desmet VJ, Gerber M, Hoofnagle JH, Manns M, Scheuer PJ. Classification of chronic hepatitis: diagnosis, grading and staging. Hepatology 1994;19:1513-19.

4 Liaw Y-F, Tai D-I, Chu C-M, Chen T-J. The development of cirrhosis in patients with chronic type B hepatitis: a prospective study. Hepatology 1988;8:493-6.

5 Cooksley WGE, Bradbear RA, Robinson W, Harrison M Halliday JW, Powell LW, et al. The prognosis of chronic active hepatitis without cirrhosis in relation to bridging necrosis. Hepatology 1986;6:345-8.

6 Scheuer PJ, Ashrafzadeh P, Sherlock S, Brown D, Dusheiko GM. The pathology of hepatitis C. Hepatology 1992;15: 567-71.

7 Bach N, Thung SH, Schaffner F. The histological features of chronic hepatitis $\mathrm{C}$ and autoimmune chronic hepatitis: a comparative analysis. Hepatology 1992;15:572-7. 
8 Lefkowitch JH, Schiff ER, Davis GL, Perrilo RP, Lindsay K, Bodenheimer HC, et al. Pathological diagnosis of chronic hepatitis C. A multicenter comparative study with chronic hepatitis B. Gastroenterology 1993;104:595-603.

9 Schuppan D. Structure of the extracellular matrix in normal and fibrotic liver: Collagens and glycoproteins. Semin Liver Dis 1990;10:1-10.

10 Gressner AM. Liver fibrosis: perspectives in pathobiochemical research and clinical outlook. Eur 7 Clin Chem Clin Biochem 1991;29:293-311.

11 Rojkind M, Giambrone MA, Biempica L. Collagen types in normal and cirrhotic liver. Gastroenterology 1985;76:7 10-19.

12 Nakatsukasa H, Nagy P, Evarts RP, Hsia C, Marsden E, Thorgeirsson S. Cellular distribution of transforming growth factor- $\beta 1$ and procollagen types I, III and IV transcripts in carbon tetrachloride-induced rat liver fibrosis. $\mathcal{F}$ Clin Invest 1990;5:1833-43.

13 Biagini G. Liver fibrosis and extracellular matrix. $\mathcal{F}$ Hepatol 1989;8:115-24.

14 Zern MA, Czaja MJ, Weiner FR. The use of molecular hybridization techniques as tools to evaluate hepatic fibrogenesis. In: Rojkind M, ed. Connective tissue in health and disease. Boca Raton, FL: CRC Press, 1990:99-122.

15 Bachem M, Meyer D, Melchior R, Sell KM, Gressner AM. Activation of rat liver perisinusoidal lipocytes by transforming growth factors derived from myofibroblast-like cells. A potential mechanism of self perpetuation in liver fibrogenesis. $\mathcal{F}$ Clin Invest 1992;89:19-27.

16 Sajus $M$, Olivi $M$, Vidaud D, Mathurin P, Opolon P, Poynard $\mathrm{T}$, et al. Analysis of $\mathrm{HCV}$ genotypes by a fluorescent competitive oligonucleotide priming PCR (COP-PCR) [abstract]. Hepatology 1994;20:244a.

17 The METAVIR cooperative group. Inter- and intraThe METAVIR cooperative group. Inter- and intra-
observer variation in the assessment of liver biopsy of chronic hepatitis C. Hepatology 1994;20:15-20.

18 Knodell KG, Ishak KG, Black WC, Chen TS, Craig R, Kaplowitz N, et al. Formulation and application of a numerical scoring system for assessing histological activity in asymptomatic chronic active hepatitis. Hepatology 1981; $1: 431-5$.

19 Chomczynski P, Sacchi N. Single-step method of RNA isolation by acid guanidium thiocyanate-phenol-chloroform extraction. Analyt Biochem 1987;162:156-9.
20 Foley KP, Leonard MW, Engel JD. Quantitation of RNA using the polymerase chain reaction. Trends Genet 1993;9: 380-5.

21 Bedossa P, Peltier E, Franco D, Poynard T, Lemaigre G. TGF $1 \mathrm{mRNA}$, protein and receptors in normal human liver, cirrhosis and hepatocellular carcinomas. Hepatology 1995;21:760-6.

22 Castilla A, Prieto J, Fausto N. Transforming growth factor- $\beta 1$ and $\alpha$ in chronic liver disease. $N$ Engl $\mathcal{F} \mathrm{Med}$ 1991;324:933-6.

23 Annoni G, Weiner F, Zern MA. Increased transforming growth factor- 1 gene expression in human liver disease. $\mathscr{F}$ Hepatol 1992;14:259-64.

24 Nakatsukasa H, Evarts RP, Hsia C, Thorgeirsson SS Transforming growth factor beta 1 and type I procollagen transcripts during regeneration and early fibrosis in rat liver. Lab Invest 1990;63:171-80.

25 Wang AM, Doyle MV, Mark DF. Quantitation of mRNA by the polymerase chain reaction. Proc Natl Acad Sci USA 1989;86:9717-21.

26 Gilliland G, Perrin S, Blanchard K, Bunn HF. Analysis of cytokine mRNA and DNA: detection and quantitation by competitive polymerase chain reaction. Proc Natl Acad $S_{c i}$

27 Malizia G, Brunt EM, Peters MG, Rizzo A, Broekelmann TJ, McDonald JA. Growth factor and procollagen type expression in human liver disease. Gastroenterology' 1995; 108: $145-56$.

28 Milani S, Herbst H, Schuppan D, Surrenti C. Transforming growth factors beta 1 and beta 2 are differentially expressed in fibrotic liver disease. Am f Pathol 1991;139:1221-29.

29 Roulot D, Durand H, Coste T, Rautureau J, Strosberg AD, Benarous R, et al. Quantitative analysis of transforming growth factor $\beta 1$ messenger RNA in the liver of patients with chronic hepatitis C: Absence of correlation between high levels and severity of disease. Hepatology 1995;21:298-304.

30 Martinot-Peignoux M, Marcellin P, Pouteau M, Castelnau C, Boyer N, Poliquin M, et al. Pretreatment serum hepatitis $\mathrm{C}$ virus $\mathrm{RNA}$ levels and hepatitis $\mathrm{C}$ genotype are the main and independent prognostic factors of sustained response to interferon alfa therapy in chronic hepatitis $C$. Hepatology 1995;22:1050-7. 